\title{
BUSINESS PROCESSES IN TIMES OF CRISIS
}

\author{
Nataša Dragišić \\ Jelena Joković
}

https://doi.org/10.31410/itema.2018.694

\begin{abstract}
The main part of a company is made of its Business processes. Companies are confronted with major changes in their business environment which are global economic and financial crisis and also a steady increase in the expectations of the company's customers. In this modern business conditions all companies are forced to adapting to modern business, both in terms of demand and supply and all of that in order to stay in this demanding market, which is a major problem for the business. Continuous improvement and Business process reengineering is required nowadays on the modern way of business, especially because this is a time of economic crisis. The main subjects of research in this paper are reengineering and improvement of business processes in times of crisis, beginning with the analysis of the current condition of business processes towards presenting more efficient business operations in the times of the crisis.

There is demanded a different approach of improving and Business process reengineering in times of crisis than in peaceful business times. The same Business process reengineering which usually gives good results is not appropriate enough for a market which is going through an economic crisis. The target of the reengineering is establishment of changes which are defined and based on the demand and market needs. Additionally, as a subject of research in this paper will be processed the way of increasing efficiency in a particular company during the economic crisis. As well, a mode of improving and Business process reengineering, and therefore what is accomplished by using and applying certain methods.

There is an example in this paper which shows how good results can be achieved and accomplished by using certain methods in the company during the crisis with adequate changes, also the methodology for better business results, method of defining the business process management plan in times of crisis, planning phase and realization of plans was presented. The purpose of this paper is to emphasize the importance of managing business processes, especially during the crisis, and how good plan and organization of processes and employees can help companies to overcome the crisis without consequences and to achieve good results in the crisis period.
\end{abstract}

Keywords: business processes, crisis, efficiency, reengineering, changes

\section{INTRODUCTION}

$\mathrm{F}$ unctioning of any company without business processes can't be imagined. Management of business processes achieves the company's success, efficiency and effectiveness of operations. Today, in a global economy that is under the influence of globalization expanding its market, and thus competition is approaching, many companies are looking for ways to increase productivity and reduce operating costs. The modern organization must set its goals before it successfully decides on the implementation of a strategy for the proper management of business processes. A large number of facts points to the significance of the process. Processes are a set of activities aimed at achieving a particular result that has value for the customer of a product or service user [6]. The process is a set of activities that transform 
one or more inputs and create an output that has a value for the user [2]. The business process is defined as a series of steps designed to create a product or service. The process is a set of related activities that are undertaken in response to a particular event in order to create an output $[5]$.

What is important for a business process manager is a constant improvement in business processes. Continuous analysis of existing processes, problem identification and the adoption and implementation of strategies and methods are the key to the good business processes and their improvement. It should be noted that improving the process is not the only solution to the problem or a unique way to achieve the organization's results. Although process improvement or redesign can make significant progress in an organization's business, success will not happen unless there is a link between processes with strategies and goals. The strategy is very important and the strategy that will be applied depends on the goal that we want to achieve. When there are problems to be solved, the restructuring of business processes is being analyzed, which helps organizations to return to the beginnings and re-examine the very beginnings of the organization's work. The most important thing about reengineering business processes is the process itself, so the reengineering of business processes focuses on processes, not on jobs, situations, tasks or people.

As already mentioned, business processes are very important for the functioning of one company, and the success and position of the company on the market depends on them. When managing business processes properly, then all the processes and sub processes are constantly analyzed, and there is one continuity in the implementation of changes and improvements that are important to the company itself and the positive results of the business. When this is not the case and when the processes are not working and it is not managed in an adequate way, there is a problem. Typically, the problems of business process mismatches are immediately apparent on business results as reflected in dissatisfaction with customers.

Nowadays, the challenge for managers of modern organizations is to successfully coordinate the activities of these units and utilize their knowledge and business skills for the benefit of the organization as a whole. Very often the work of these business units is not synchronized and in accordance with the mission or purpose of the organization.

In the continuation of the paper the methods of improving business processes will be presented, as well as the methods used in the specific Automobile Company in the conditions of the crisis. The situation and the implementation of the method that will help company to improve business processes will be presented and explained.

\section{BUSINESS PROCESSES, CRISIS AND REENGINEERING}

The biggest problem in redefining and improving existing business processes is the current economic theory that when the world economy entered the recession itself, was in crisis, because its existing knowledge fails to explain the causes of the current situation and to recommend solutions for its overcoming. The same applies to the current reengineering theory that is based on the principles of subjective change and improvement of business processes, which as such does not correspond to the character and dynamics of current and expected even more intense future changes. Business process management is a managerial approach that focuses on adapting organizational aspects to the needs and demands of customers. It is a holistic approach to governance, which promotes efficiency and effectiveness in business, encourages innovation, organizational flexibility and the use of high technology [7]. The 
management of business processes in times of crisis and their improvement and reengineering are of great importance. If a particular company is going through a crisis period, it is important to analyze the existing situation and for which business process activities need changes. After applying the method of improvement and reengineering, it is necessary to record whether progress has been made and whether the processes have been improved and whether as such can affect the company's better performance and efficiency.

Crises are the moment of fracture, the moment when it is understood that it is necessary to make very important decisions and proceed on the basis of them to take action in order to eliminate all the factors that have contributed to the disruption of the normal functioning of the system. Any problem or occasion that arises from a change requires a solution, which leads to a new change, so that the company again encounters a new reality and new problems or opportunities. Problems are constantly there and as long as there are changes, there will be problems and opportunities. The cycle of change and the problem can be simply shown in the following way:

\section{$\mathrm{CHANGE} \rightarrow$ PROBLEM $\rightarrow$ SOLUTION or CRISIS}

The longer company is waiting and delaying the resolution of a problem, most likely the problem will turn into a crisis. In order to solve any problem, it must be understood beforehand, also the understanding of the essence of the problem helps the management of the company that is the one who must implement methods for achieving goals of the company.

Modern business conditions require business organizations to adapt their strategies and business practices. The global economy creates a belief in the equal functioning of business organizations, but also results in stronger competition. On the global contemporary market, the best of the best win, no matter where they are from. The most important reasons for a reengineering of business processes are the rapid changes that are taking place in the world, consumers who are increasingly demanding and competition that is getting tougher. The most important reasons for the crisis are the changes taking place in the world, customers or consumers that are becoming more and more demanding and competition that is becoming even more severe.

Business process reengineering required a complete reorganization of a company based on business processes. This is a radical solution, but it was well perceived by companies that were faced with major problems with regard to competition and change. The goal of reengineering the business processes of each organization is to raise the effectiveness of these activities to a higher level.

The first clear definition for BPR is that this is a fundamental change in thinking and a radical redesign of business processes that are used in order to achieve great improvements in problematic, modern performance measures, such as cost, quality, service and speed [7]. Business process reengineering represents a process of transformation in a radical way in order to achieve great improvements in terms of quality and productivity [1].

Reengineering is done in several phases such as the selection of the process, the team that will carry out the process, understanding the already existing process, planning the process, develop the vision and further communicate the future process and details of the plan and execution actions. This is the way to emphasize influence of the new economic crisis, since business must be modified to the newly emerging situation where production and service processes need to be maximally adapted to new market demands and reduced demand. In this way, reengineering is 
presented like a fundamental reflection and a radical redesign of business processes to achieve dramatic improvements in critical, essential performance measures, such as cost, quality, service and speed. This definition contains four Keywords: fundamentally, radically, dramatically and processes. The central place in the philosophy of reengineering belongs to processes, and this term refers to the design of the process. The revolution of the reengineering had two main themes: the first is when organization is around the process, and the other is to organize the processes in a superior way. The concept of reengineering is closely related to the need for companies to reinvent themselves. It is a new business model to achieve company's inventiveness. Reengineering has the task of influencing on whole business system of the company in achieving better results on the dynamic jump of business [4]. As already mentioned, reengineering is fundamentally principled, and its program can be implemented in two categories, both at company and process level. At the company level, it means executing all radical and fundamental activities that will include the entire business of one company. It is most often due to the fact that competition is fairly pronounced on the market and there is a need for the implementation of changes to be made by the top management. It implies a series of procedures to be carried out, including the change in the organizational structure, the rewarding process of employees in the organization, the improvement of motivation and the establishment of a stronger organizational culture. At the level of the process radical changes imply in terms of redesigning the basic process and analyzing management that results in defining problems and at the same time eliminating: it implies what processes the company needs to redesign and how the procedure will be performed [9].

Based on the above, it can be mentioned that the reengineering of business processes as a management tool is necessary in order to successfully implement the application of innovations and fundamental redesign of the entire business, all in order to be in accordance with the new business flows.

\section{BUSINESS PROCESS REENGENIRING METHODOLOGIES}

The most common methodologies for improving business processes are kaizen, lean and Six Sigma. Depending on the company's activity and its goals, a decision is made which methodology is going to be in use.

Lean is a production philosophy that, when implemented, shortens the time from the customer's order to the delivery of the finished product, eliminating all sources of waste and losses in the production process. The basic principle of Lean production is to produce exactly what the customer wants, both in terms of quality and quantity, which is dictated by the market.

Six Sigma is a business strategy which was developed by Motorola in USA in 1986. The goal is to improve the quality of final products by defining and eliminating the causes that lead to errors, thus minimizing variability in production and business processes [8].

Kaizen implies the constant improvement production business processes and management. Kaizen is one of the most suitable methods of continual improvement. It enables incremental process improvement, and it is also inexpensive and flexible. At the same time, it provides the ability for employees to respond quickly, effectively and efficiently to all the changes in turbulent and complex business environment. Kaizen is today recognized as a world movement with the aim of eliminating all forms of wasting and economical resource use in production and service processes. In the Kaizen project people are the key to success, so it is important to support the process. Therefore, it is important to explain to employees what is expected of the 
improvement process and what their mission is [3].

The Kaizen methodology was used on a concrete case of a car company which is being in a financial crisis. Employees are the key of a change; in this case, they have worked as a team, have changed a continuous way of doing business and thinking which have not brought positive results. Education and trainings helped out to all employees to implement the Kaizen approach.

When it comes to selling new cars, the problem in the automotive industry has arisen in the last few years because of a concern about the cars as a source of air pollution. Standards of air pollution were increased recently.

Consequently, the set-up of E6 engines that are not suitable for customers contributed to this, as they require significantly more expensive maintenance. Regulations of air pollution in the EU, which is related to cars, have existed since the 1970s, and have since continually been tightened, so that from the Euro 1 standard in 1992. the Euro 6 standard has been in force since 2014. All diesel vehicles have significantly reduced the emissions of nitrogen oxides after that regulation was set up. The emission of harmful gases is limited to $80 \mathrm{mg} / \mathrm{km}$, which is more than $50 \%$ less in comparison to the Euro 5 standard.

The increase of Euro standards brought many problems. During the survey, the director of a car-servicing company was interviewed. He is directly informed about contemporary issues, developments and problems as well. The demand for new cars grows with the increase of a living standard and individual capabilities and cultural specificities in each country. As mentioned above, the legal standards prescribe the production of vehicles which have the most modern technology that fits to required standards, and this directly affects on the production of vehicles, as well as the costs of installing special filters that purify harmful gases by retaining particles of soot and other modern devices which reduce the emissions of harmful gases. All of this implies on a final product price increase, which consequently has the effect of reducing the demand for cars, and this leads to a reduction in the number of employees in the automotive industry. GDP is also reduced, and public consumption of other goods and services is reduced, so the overall economic capacity is reduced.

\section{AUTOMOTIVE INDUSTRY IN CRISIS}

The main subject of this paper refers to the automotive companies in crisis, due to the decrease in cars sale, which was influenced by several factors. It also presents the company management, whose director was interviewed, that has found the solution for improvement of business processes. These changes in business led the company to better results. The main part in the implementation of reengineering are employees, so the management decided that there won't be dismissal of employees or cutting down salaries, even though the volume of work was reduced and the costs of work have increased. Instead, they made a resolution that all employees will work one hour longer every day, and they also started working on Saturdays. Before this resolution, only half of the all employees have worked on Saturdays. This resulted in more work assignments being done, and employees working more effectively as a team, making the right decisions for the company to improve its position on the market.

The first step was to define the problem with sales and customer service that was causing reduced car sale and providing services. In addition, they needed to find out what the reason for the customer complaints are and what makes them unsatisfied. The next task was to identify problems in production, what are the most common issues and how can they be solved in order 
to reduce clients' dissatisfaction and the number of complaints. After that, all of the elements were analyzed in order to conduct reengineering in this process. In the final phase, there were implementation and control, implementation of improvement and prevention of possible failures that could possibly cause much bigger problems.

From the sales point of view, the budget disposal decisions were made. It has been decided to invest in a marketing strategy on a regional level with the support from a general distributor who dictates the rules. Besides advertisements and promotions, well-known people from the automotive industry are engaged to promote cars, in order to attract new customers. Also, the company introduces the offer - selling old one for the new one - so the owners of a car with the E5 engine got a discount on a new car with the E6 engine, in order to improve the sales. Legislation in the EU had forced citizens to adapt and to buy new cars that are in line with the law and regulations.

According to the latest legal standards, the current Euro standard is 6.2. The challenge is big, but it's not new, because these are the standards for climate protection. Until recently, internal combustion engines were one of a kind technology, including diesel engines in order to achieve a European standard target of 95 grams of $\mathrm{CO}_{2}$ emission from 2020/2021. According to the recently available information, a petrol engine with a SCR catalytic converter is produced, which requires the injection of fluid UREA and DPF filter, which require the addition of a certain DPX liquid after passing the prescribed kilometers. In the long term, the responsible ones in that area agreed that more battery-powered electrical will occur, as the before mentioned system is extremely sensitive to the smallest changes, and as of the reports that the Euro standard has not been reached yet.

Companies that are directly dependent on the automotive industry and produce raw materials and parts that are necessary for the production, have a major problem. Such enterprises (not only in the car industry, but also small and medium-sized enterprises as well) are the heart of the economic development and prosperity of national economics. They do not produce, do not hire, do not take loans, guarantees, credit lines, and do not even earn money. In each country, economic development slows down to a complete stop. That is why governments of the crisishit countries inject billions into the car industry recovering [10].

However, due to the overall situation, various scandals have arisen, even falsifying the values of harmful exhaust gases. The subject of the investigation is a well-known car company which has launched cars with software for manipulating the measured values of exhaust gases, which was discovered by monitoring the car's operation during a few hours. In the first few hours, the car produces allowed amount of harmful substances, while after a certain time the value of the pollution raised that much that it fits to Euro 4 standards.

\section{CONCLUSION}

This paper is about business processes and their improvement in the state of crisis. Business processes, as an integral part of each organization, represent the foundation of existence and business. Proper business process management achieves positive business results, minimizes operating costs by making efficient use of available resources and improving processes, while continuously innovating and delivering top quality products for the most important clients by adequate employee, which would result in an increased revenue and profit for the founder's and employees' satisfaction as well. The requirement for the business process reengineering during the crisis is explained, as well as what crisis and changes bring with them. 
Certain case of the Automotive company during the crisis is researched for this paper, and the research shows how business process management works and moreover the importance of the company's management's right decisions. This includes implementing adequate strategies for meeting certain goals. Some of the solutions to overcome the crisis are training for all employees, increasing the work hours, as well as introducing working Saturdays. Employees still have the same salary, but they spend more time at work using it to design the best solution and strategy for further business. All of this is to avoid firing people. Despite of the same salary, employees feel necessary, important and significant because they participate in making big decisions about their company's business. One of the changes is also that a bigger budget is set aside for advertising. The market is being surveyed and a target group is determined. They decided that the targeted audience is younger population, so a well-known personality that's a model and an example in eyes of the young people was engaged in advertising.

As one of the main causes of the crisis in this industry is the change in the air pollution standards for vehicles, the biggest problem is customer dissatisfaction caused by formed change in standards and regulations. New legal regulations have significantly increased the cost of car maintenance. Owners of the cars with E5 and lower standard engines are already influenced because they own relatively new cars that are threatened by the ban and very high maintenance costs, which means that they will eventually have to replace those models with newer ones, that have even higher maintenance costs because of the requirement of the fluids that are indispensable for achieving certain Euro standards.

Better business management has achieved by making changes in the working teams, staff training, and even increase in working time has contributed to improvement. Marketing was done the right way and it attracted a specific targeted group of younger people. The main problem is the new standard, but this is the legal rule and neither the company nor an individual can revise much. The company has offered subventions like replacing the old cars with new ones as well as offering discount on new cars.

\section{REFERENCES}

[1] Bergeron, F., \& Falardeau, J. (1994) Le reingenierie des processus d'affaires dans les enterprises canadiennes. Montreal, Les Editions Transcontinentales.

[2] Hammer, M., \& Champy, J. (1993) Reengineering the Corporation, A Manifesto for Business Revolution, New York, Harper Business.

[3] Kanji, G. K., Asher, M. (1996) 100 methods for total quality management, London, Sage Publications.

[4] Mašić B. (2001) Strategijski menadžment, Beograd, Univerzitet Braća Karić.

[5] Rummler, G. A., \& Brache, A. P. (1995) Improving Performance, How to manage the white space on the organization chart, 2. izdanje, San Francisco, Jossey-Bass.

[6] Vasiljević, D., \& Slović, D. (2015) Kaizen, japanska paradigma poslovne izvrsnosti, Beograd, Fakultet organizacionih nauka Univerziteta u Beogradu.

[7] Vom Brocke, J., \& Rosemann, M. (2010) Handbook on Business Process Management 1. , Introduction, Methods, and Information Systems, Berlin, Springer.

[8] Ziegenbein, K. (2008) Kontroling, Zagreb, RriF plus.

[9] Živanović, N., Živanović, V., \& Živanović, M. (2013) Reengineering capacity exspansion. I Zbornik sa Nacionalne konferencije sa međunarodnim učešćem "Menadžment, sport, turizam" MASTA - 2013, Banja Luka, Republika Srpska (Bosna i Hercegovina), 29.03.2013., str. 30 . 
[10] Đermanović, D. (2008) Svetska ekonomska kriza - Autoindustrija: http://draganadjermanovic.com/razmisljanja/svetska-ekonomska-kriza-autoindustrija/ 